PNL-2531

UC-60

\title{
Wind Direction Change \\ Criteria for Wind Turbine Design
}

W. C. Cliff

January 1979

Prepared for the U.S. Department of Energy under Contract EY-76-C-06-1830

Pacific Northwest Laboratory

Operated for the U.S. Department of Energy by Battelle Memorial Institute 
This report was prepared as an account of work sponsored by the United States Covernment. Neither the United States nor the Department of Energy, nor any of their employees, nor any of their contractors, subcontractors, or their employees, makes any warranty, express or implied, or assumes any legal liability or responsibility for the accuracy, completeness or usefulness of any information, apparatus, product or process disclosed, or represents that its use would not infringe privately owned rights.

The views, opinions and conclusions contained in this report are those of the contractor and do not necessarily represent those of the United States Government or the United States Department of Energy.

\author{
PACIFIC NORTHWEST LABORATORY \\ operated by \\ BATTELLE \\ for the \\ UNITED STATES DEPARTMENT OF ENERGY \\ Under Contract EY-76-C-06-1830
}

\author{
Printed in the United States of America \\ Available from \\ National Technical Information Service \\ United States Department of Commerce \\ 5285 Port Royal Road \\ Springfield, Virginia 22151
}

Price: Printed Copy $\$$

; Microfiche $\$ 3.00$

$\begin{array}{cc}\text { Pages } & \begin{array}{c}\text { NTIS } \\ \text { Selling Price }\end{array} \\ 001-025 & \$ 4.00 \\ 026-050 & \$ 4.50 \\ 051-075 & \$ 5.25 \\ 076-100 & \$ 6.00 \\ 101-125 & \$ 6.50 \\ 126-150 & \$ 7.25 \\ 151-175 & \$ 8.00 \\ 176-200 & \$ 9.00 \\ 201-225 & \$ 9.25 \\ 226-250 & \$ 9.50 \\ 251-205 & \$ 10.75 \\ 276-300 & \$ 11.00\end{array}$




\section{9}

WIND DIRECTION CHANGE CRITERIA

FOR WIND TURBINE DESIGN

W. C. Cliff

January 1979

Prepared for the U.S. Department of Energy under Contract EY-76-C-06-1830

PACIF IC NORTHWEST LABORATORY

Richland, Washington 99352 



\section{ACKNOWLEDGMIIENTS}

The author would like to thank Drs. Jim Connell and Chris Doran for their review and comment. The author also wishes to express his appreciation to George P. Tennyson, Donald D. Teague and Carl Aspliden of the Department of Energy (DOE) Wind System Branch (WSB) for their support, review and advice. 

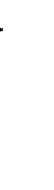


\section{SUMMARY}

This paper presents a method for estimating the root mean square (rms) value of the wind direction change, $\Delta \theta(\tau)=\theta(\tau+\tau)-\theta(\tau)$, that occurs over the swept area of wind turbine rotor systems. An equation is also given for the rms value of the wind direction change that occurs at a single point in space, i.e., a direction change that a wind vane would measure. Assuming a normal probability density function for the lateral wind velocity change and relating this to angular changes, equations are given for calculating the expected number of wind direction changes, larger than an arbitrary value, that will occur in $1 \mathrm{hr}$ as well as the expected number that will occur during the design life of a wind turbine. The equations presented are developed using a small angle approximation and are, therefore, considered appropriate for wind direction changes of less than $30^{\circ}$. The equations presented are based upon neutral atmospheric boundary-layer conditions and do not include information regarding events such as tornados, hurricanes, etc. 


\section{CONTENTS}

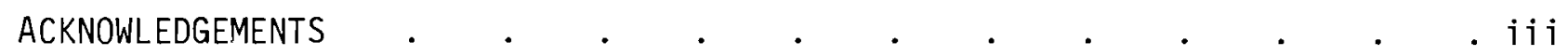

SUMMARY

INTRODUCTION

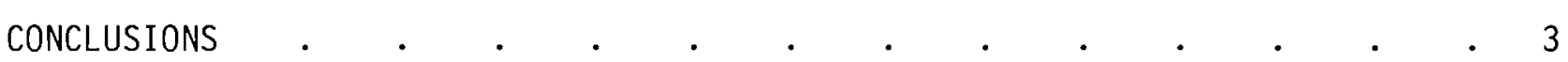

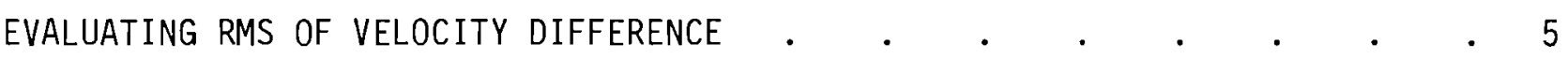

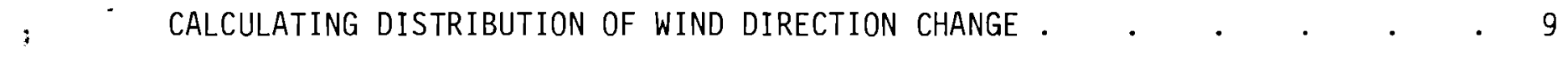

COMPUTING THE TOTAL NUMBER OF EVENTS DURING

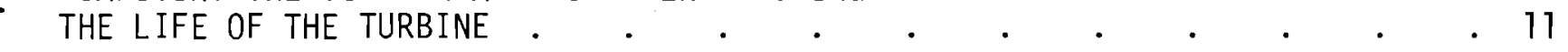

APPENDIX A - PROCEDURE FOR CALCULATING DIRECTION CHANGES . . . . . A-1 


\section{$\underline{\text { INTRODUCTION }}$}

In many cases, the wind turbine design engineer needs to know wind characteristics that engulf all or part of the turbine rotor system because a spatialfiltering effect, depending on the size of the wind turbine rotor system, must be accounted for in order to provide wind characteristic design inputs. One such input is the wind direction change, $[\theta(t+\tau)-\theta(t)]$, which occurs over time $(\tau)$. The direction change, which is also averaged over the swept area of a rotor system, is less severe than the maximum direction change occurring at a point within the swept area. That is, within the swept area of the rotor, areas of direction change greater than the average direction change as well as areas of lesser change occur simultaneously.

This paper presents formulas for estimating the direction change encountered over the swept area of the rotor system. The formulas are generic and may be used for any size of wind turbine system operating in strong wind conditions. A meter-kilogram-second (mks) system of units is used in this report. 


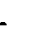

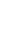




\section{CONCLUSIONS}

A solution for the rms value of direction change, $\Delta \theta(\tau)=[\theta(t+\tau)-\theta(t)]$, encountered over the disk of rotation of a wind turbine is derived in Equation (6) of this report. Assuming that the probability density function for the lateral velocity difference is normal, Equation (9) estimates the expected hourly number of direction changes that exceed a given value. To compute the expected number of direction changes that exceed a given level during the life of a machine, Equation (10), which includes the hourly mean longitudinal wind component climatology for the turbine site, is given. If the designer wishes to estimate the once in 10,30, $100 \mathrm{yr}$, etc., direction change, Equation (10) should be evaluated according to a set number of years for increasing values of $X$ (direction change) until $N_{T} \simeq 1$, where $N_{T}$ equals the total number of expected direction changes, greater than $X$, which occurs in a given number of years.

The value of $X$ that yields $N_{T} \simeq 1$ would be the value of $\Delta \theta(\tau)$ that can be expected to be exceeded once in a given number of years ( $Y$ ). These exceedance values must stay within the approximation constraints imposed on the deviations (i.e., less than $30^{\circ}$ ), and the values obtained for the long-term exceedance values are, at best, engineering guesses with little experimental validation. 


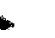

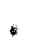


This section derives an expression for the root mean square (rms) value of the wind direction change over the disk of rotation of a wind turbine.

The rms of change in the wind direction change is defined by the following equation:

$$
\sigma_{\Delta \theta}(\tau)=\left[\frac{1}{T} \int_{0}^{T}[\theta(t+\tau)-\theta(t)]^{2} d t\right]=\overline{[\theta(t+\tau)-\theta(t)]^{2}}
$$

where

$$
\begin{aligned}
\theta(t)= & \text { wind direction angle at time }(t) . \quad \text { ( } 0 \text { reference angle generally taken } \\
& \text { parallel to the mean direction of flow.) } \\
\sigma_{\Delta \theta}(\tau)= & \text { rms of the wind direction change } \\
\tau= & \text { time over which the directional difference takes place } \\
T= & \text { time period for defining turbulence (generally considered between } \\
& 10 \text { min to } 7 \mathrm{hr}) \\
t= & \text { time } \\
\tau- & =\frac{1}{T} \int_{0}^{T}() \mathrm{dt}
\end{aligned}
$$

Equation (1) may be expanded and written as:

$$
\sigma_{\Delta \theta}(\tau)={\overline{\left[\theta^{2}(t+\tau)+\theta^{2}(t)-2 \theta(t) \theta(t+\tau)\right]}}^{\frac{1}{2}}
$$

For small angles (less than $30^{\circ}$ ) the following formula will be used to approximate the angle, $\theta$.

$$
\theta(t) \simeq \frac{v(t)}{\bar{U}_{h}}
$$


where

$$
\begin{aligned}
v(t) & =\text { lateral component of velocity at time }(t) \\
\bar{U}_{h} & =\text { hourly mean longitudinal component of wind speed at hub height }
\end{aligned}
$$

Using the approximation given by Equation (3) and noting that the assumed distribution shape for $v(t)$ is transferred to $\theta(t)$ and that $\overline{\theta^{2}(t+\tau)}=\overline{\theta^{2}(t)}$ when $\tau$ is short compared to $T$, Equation (2) becomes:

$$
\sigma_{\Delta \theta}(\tau)=\frac{\sqrt{2}}{\bar{U}_{h}} \overline{\left[v^{2}(t)\right.}-\overline{v(t) v(t+\tau)]}^{1 / 2}
$$

Equation (4) may now be written in its spectral equivalent form as:

$$
\begin{aligned}
\sigma_{\Delta \theta}(\tau) & =\frac{\sqrt{2}}{\bar{U}_{h}} \sigma v\left[\int_{0}^{\infty} \phi_{v}(f) d f-\int_{0}^{\infty} \phi_{v}(f) \cos 2 \pi f \tau d f\right]^{\frac{1}{2}} \\
& =\frac{\sqrt{2}}{\bar{U}_{h}} \sigma_{v}\left[\int_{0}^{\infty} \phi_{v}(f)\left[\begin{array}{ll}
1 & \cos 2 \pi f \tau] d f
\end{array}\right]^{\frac{1}{2}}\right.
\end{aligned}
$$

where

$$
f=\text { frequency }(\mathrm{Hz})
$$

$\phi_{V}(f)=$ normalized power spectrum of the lateral wind component, $v$.

Any standard atmospheric spectral model can be used in Equation (5) to solve for $\sigma_{\Delta \theta}(\tau)$. However, the results would only be applicable for a system that senses a smal1 volume (e.g., anemometer systems). When systems sample larger volumes of space, Equation (5) must be modified to adjust for the spatial filtering effect of averaging over a larger volume of space.

One approach for adjusting Equation (5) to account for system size would be to introduce a filter function to act as a high frequency cutoff. This paper does not pursue this approach by which a potential exists for obtaining a closedform solution using the Dryden ${ }^{(1)}$ atmospheric spectra and a first-order filter 
with the $3-d b$ (half power) point set at a frequency equal to $\bar{U}_{h} / D$, where $D$ is the diameter of the turbine rotor system. Such a closed-form solution would be advantageous, because the user would not have to contend with a numerical integration.

A second approach, which is used for this paper, is to use a truncated spectra with the truncation occurring at a frequency equal to $\bar{U}_{h} / D$. Using the engineering approximations that $\sigma_{y} \simeq 0.75 \sigma_{u}{ }^{(2)}\left(\sigma_{u}=\right.$ rms of longitudinal wind component) and $\sigma_{u} \simeq \bar{U}_{h} / 1 n z_{h} / z_{0}(3)$ and truncating the spectra, Equation (5) may be written as:

$$
\sigma_{\Delta \theta}(\tau) \stackrel{\sim}{=} \frac{1.1}{\ln \left(z_{h} / z_{0}\right)}\left[\int_{0}^{\bar{U}_{h} / D} \phi_{v}(f)(1-\cos 2 \pi f \tau) d f\right]^{\frac{1}{2}}
$$

where

$$
\begin{aligned}
& D=\text { diameter of wind turbine, } m \\
& \bar{U}_{h}=\text { hourly mean longitudinal wind component at hub height, } \mathrm{m} \mathrm{sec}-1 \\
& z_{0}=\text { surface roughness, e.g., } \\
& z_{0}=0.0005 \mathrm{~m} \text { (smooth terrain) } \\
& z_{0}=0.05 \mathrm{~m} \text { (moderate terrain) } \\
& z_{0}=0.34 \mathrm{~m} \text { (rough terrain) } \\
& z_{h}=\text { height of measurement, } m \text { (hub height of wind turbine). }
\end{aligned}
$$

The results obtained by filtering as in the first approach and the results obtained by spectral truncation as in the second approach are within 5\% of one another. Also the results are not a strong function of D; that is, a small change in $D$ will not significantly affect the results. The truncation of the spectra was selected to be at a value of frequency equal to $\bar{U} / D$ until better values can be determined experimentally.

It is recommended that the von Karman spectra be used for $\phi_{v}$ in Equation (6). The von Karman spectra, which is internationally accepted and allows for spectral change as a function of surface roughness, is as follows: 


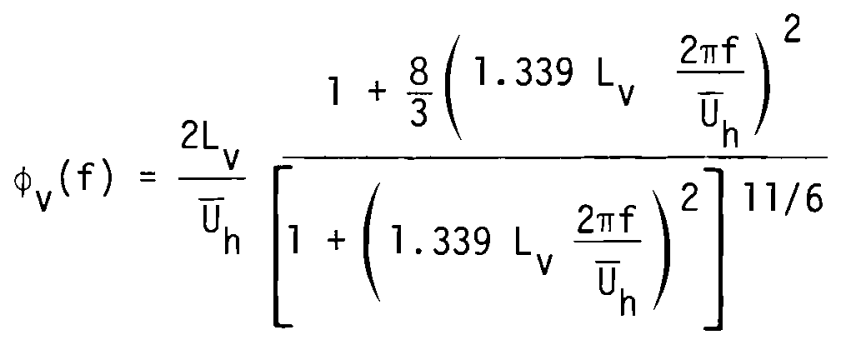

where $L_{v}$ is given by the following equation: (4)

$$
L_{v}=\frac{5.1 z_{h}^{0.48}}{z_{0}^{0.086}}
$$

(Note: $\sigma_{\Delta \theta}$ is a function of $z_{0}, \bar{U}_{h}, z_{h}$ and $\tau$.) 


\section{CALCULATING DISTRIBUTION OF WIND DIRECTION-CHANGE}

Assuming that wind direction changes are Gaussian distributed, the following formula (9) gives the approximate number, $N$, of direction changes, $\Delta \theta(\tau)=\theta(t+\tau)-\theta(t)$, per hour that exceed a given value, $x$. (The righthand term is an approximation to the double-sided integral of the normal distribution $(5)$.) The number $N$ represents an absolute number of $\Delta \theta(\tau)$, which should occur. Equal numbers should occur clockwise as counterclockwise; thus, if only the clockwise or counterclockwise $\Delta \theta(\tau)$ 's are desired the calculated number, $N$, should be divided by two.

$$
N[\Delta \theta(\tau)>x]=\frac{3600}{\tau}\left(1+d_{1} z+d_{2} z^{2}+d_{3} z^{3}+d_{4} z^{4}+d_{5} z^{5}+d_{6} z^{6}\right)^{-16}
$$

where:

$$
\begin{aligned}
& \tau \text { is in seconds } \\
& z=\frac{X}{\sigma_{\Delta \theta}(\tau)} \\
& d_{1}=0.0498673470 \\
& d_{2}=0.0211410061 \\
& d_{3}=0.0032776263 \\
& d_{4}=0.0000380036 \\
& d_{5}=0.0000488906 \\
& d_{6}=0.0000053830
\end{aligned}
$$

and $\sigma_{\Delta \theta}(\tau)$ is calculated using Equation $(6)$.

The first term on the right side of Equation (9) is the total number of $\Delta \theta(\tau)$ 's that occur per hour, that is, $3600 / \tau$ events per hour spaced $\tau$ seconds - apart, half being clockwise and half being counterclockwise. 
The total number of velocity changes of a given magnitude that may occur during a turbine's life should be useful in control analysis. The following equation may be used to compute the exnected number $\left(N_{T}\right)$ of direction changes (which exceed a given value) that occurs over a given number of years (Y).

$$
N_{T}[\Delta \theta(\tau)>X]=8766(Y) \int_{0}^{\infty} N p\left(\bar{U}_{h}\right) d \bar{U}_{h}
$$

where

$$
\begin{aligned}
& N_{T}=\text { total number of expected direction changes greater than } X \text {, which occur } \\
& \text { in } Y \\
& 8766=\text { number of } h r \text { in } 1 \text { yr } \\
& Y=\text { number of } y r \\
& P\left(\bar{U}_{h}\right)=\text { probability density distribution of hourly mean values of the longitudinal } \\
& \quad \text { wind component that occurs at wind turbine hub height. } \\
& \text { If only direction changes that occur while the turbine is operating are of } \\
& \text { interest, the limits of integration for Equation (10) should be from the turbine } \\
& \text { cut-in velocity to the turbine cutout velocity rather than from } 0 \text { to } \infty \text {. } \\
& \text { If a frequency distribution of the hourly mean values of the longitudinal } \\
& \text { wind component ( }\left(\bar{U}_{n}\right) \text { ) is not known for a particular site being analyzed, the } \\
& \text { Rayleigh distribution for } P\left(\bar{U}_{h}\right) \text { may be used as follows: }
\end{aligned}
$$

$$
P\left(\bar{U}_{h}\right)=\frac{\bar{U}_{h}{ }^{\pi}}{2 U_{a}^{2}} e^{\frac{-\pi \bar{U}^{2}}{4 U_{a}^{2}}}
$$

where $U_{a}$ is the annual mean longitudinal wind component at hui height. 


\section{REFERENCES}

1. John W. Kaufman, editor, Terrestrial Environment (Climatic) Criteria Guidelines for Use in Aerospace Vehicle Development 1977 Revision. NASA Technical Memorandum 78118 MSFC, AL p. 8.136, September 1977.

2. J. Counihan, "Adiabatic Atmospheric Boundary Layers: A Review and Analysis of Data from the Period 1880-1972," Atmospheric Environment, Vol. 9. Pergamon Press, Great Britain p. 889, 1975.

3. John L. Lumley, and Hans A. Panofsky, The Structure of Atmospheric Turbulence. John Wiley and Sons Inc., New York p. 155, 1964.

4. Engineering Sciences Data Unit Item No. 74031 Characteristics of Atmospheric Turbulence mean the ground, Engineering Sciences Data Unit London, England, p. 27, March 1975.

5. Lee W. Falls, A Computer Program for Standard Statistical Distributions, NASA TM X-64588, p. 10, Apri1 30, 1971. 


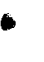

c 
APPENDIX

PROCEDURE FOR CALCULATING DIRECTION CHANGES 


\section{PROCEDURE FOR CALCULATING DIRECTION CHANGES}

The following criteria should be used for computing the angular changes in wind direction, which are encountered over the disk of rotation of a wind turbine. (Angular variation is defined as the difference in the wind angle $\theta(t+\tau)$ measured at time $(t+\tau)$ and the wind angle $(\theta(t))$ measured at an earlier time $(t)$; therefore, angular variation equals $\Delta \theta=\theta(t+\tau)-\theta(t)$.

The following formula gives the approximate number $(N)$ of angular changes, $\Delta \theta(\tau)=\theta(t+\tau)-\theta(t)$, per hour that exceeds a given value, $X$. The number $(N)$ represents the absolute number of $\Delta \theta(\tau)$ that occurs. Equal numbers should occur clockwise as counterclockwise; thus, if only the clockwise or counterclockwise $\Delta \theta(\tau)$ 's are desired the number $(N)$ calculated is simply divided by two.

$$
N[\Delta \theta(\tau)>X]=\frac{3600}{\tau}\left(1+d_{1} z+d_{2} z^{2}+d_{3} z^{3}+d_{4} z^{4}+d_{5} z^{5}+d_{6} z^{6}\right)^{-16}
$$

where:

$$
\begin{aligned}
& \tau \text { is in seconds } \\
& z=\frac{x}{\sigma_{\Delta \theta}(\tau)} \\
& d_{1}=0.0498673470 \\
& d_{2}=0.0211410061 \\
& d_{3}=0.0032776263 \\
& d_{4}=0.0000380036 \\
& d_{5}=0.0000488906 \\
& d_{6}=0.0000053830
\end{aligned}
$$




$$
\sigma_{\Delta \theta}(\tau)=\frac{1.1}{\ln \left(z_{h} / z_{0}\right)}\left[\int_{0}^{\bar{U}_{h} / D} \phi_{v}(f)(1-\cos \pi 2 \tau f) d f\right]^{\frac{1}{2}}
$$

$D=$ diameter of wind turbine, $m$

$\bar{U}_{h}=$ hourly mean longitudinal wind component at hub height, $\mathrm{m} \mathrm{sec}^{-1}$

$z_{0}=$ surface roughness, e.g.,

$z_{0}=0.0005 \mathrm{~m}$ (smooth terrain)

$z_{0}=0.05 \mathrm{~m}$ (moderate terrain)

$z_{0}=0.34 \mathrm{~m}$ (rough terrain)

$z_{h}=$ height of measurement, $m$, (hub height of wind turbine).

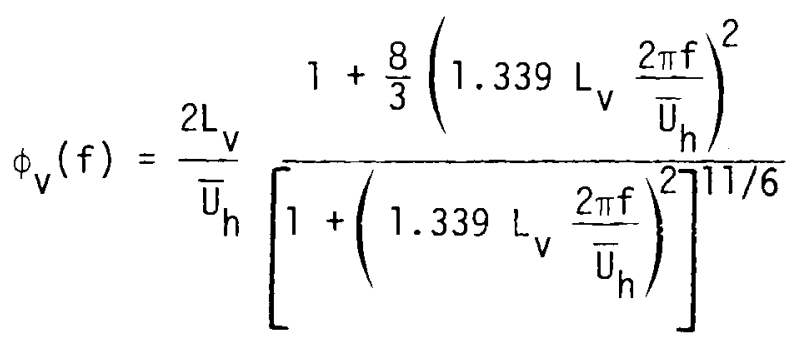

$$
L_{v}=\frac{5.1 z_{h}^{0.48}}{z_{0}^{0.086}}
$$

To calculate the total number of occurences over the life of the wind turbine, Equation (10) in the text should be used. 


\section{DISTRIBUTION}

No. of

Copies

\section{OFFSITE}

A. A. Churm

DOE Chicago Patent Group

9800 South Cass Avenue

Argonne, IL 60439

G. P. Tennyson

Department of Energy

600 E Street, N. W.

Washington, DC 20545

DOE Technical Information Center

Thomas Vonier

AWEA Windletter

2222 Q Street, N. W.

Washington, DC 20008

Dr. Paul B. Maccready, Jr.

Aerovironment, Inc.

145 Vista Avenue

Pasadena, CA 91107

Clarissa Quinlan

Alaska State Energy Office

338 Denali Street

Anchorage, AK 99501

Paul N. Vosburgh

Alcoa Allied Products

A 7 uminum Company of America

Alcoa Center, PA 15069

Dr. K. C. Spengler

American Meteorological Society

45 Beacon Street

Boston, MA 02108

Ben Wolff

American Wind Energy Association

1000 Connecticut Avenue, N. W.

Suite 1111

Washington, DC 20036
No. of

Copies

Richard Katzenberg

American Wind Energy Association

Natura 1 Power, Inc.

New Boston, NH 03070

E. J. Warchol

Bonneville Power Administration

P. 0. Box 3621

Portland, OR 97208

S. J. Hightower

Bureau of Reclamation

Denver Federal Center

Building 67, Code 254

Denver, C0 80225

M. Ginosar

California Solar Energy Commission

Energy Resources, Conservation and Development Commission

1111 Howe Avenue, Mai1 Stop 15

Sacramento, CA 95825

Robert Ball

Center for the Environment and Man, Inc.

275 Windsor Street

Hartford, CT 06120

Dr. R. J. Hawks

Clarkson College

Potsdam, NY 13676

Dr. R. N. Meroney

Colorado State University

Fort Collins, CO 80523

E. H. Gilmore

Department of Agriculture

Agriculture Research Service

Bushland, TX 79012 
L. A. Liljedahl

Department of Agriculture

Agriculture Wind Energy Program

Building 001 , Room 126 BARC-West

Beltsville, MD 20705

Douglas G. Fox

Department of Agriculture

Forest and Mounta in Meteorology

Rocky Mountain Forest and Range

Experiment Station

240 West Prospect Street

Fort Collins, CO 80521

Major T. E. Kullgren

DFCEM

USAF Academy, CO 80840

Jay Tappan

Department of Energy

State of Oregon

Labor and Industries Building

Room 111

Salem, OR 97310

Harry Moses

Department of Energy

Division of Biomedical and

Environmental Research

Mail Stop E-201

Washington, DC 20545

Carl Miner TAN-604

EG\&G Idaho, Inc.

P. 0. Box 1625

Idaho Fâls, ID 83401

Dr. Edgar Demeo

Electric Power Research Institute

3412 Hillview Avenue

Palo Alto, CA 94303

Jim Lerner

Energy Resources Conservation and Development Commission

Cal ifornia Solar Energy Office

Mail Stop 15

Sacramento, CA 95825
Dr. 011e Ljungstrom

FFA, The Aeronautical Research Institute

Forskningsstationen i Stockholm

Drottning Kristinas Vag 47

S-114 28 Stockholm, Sweden

R. B. Lawford

Fisheries \& Environment

25 St. Clair Ave. East

Toronto, Canada M4T 1M2

Dr. W. Frost

FWG Associates, Inc.

R. R. 3, Box 331

Tullahoma, TN 37388

L. Krawitz

General Electric Company

P. 0. Box 8555

Philadelphia, PA 19101

R. C. Koch

Geomet, Inc.

15 Firstfield Road

Gaithersburg, MD 20760

C. G. Justus

Georgia Institute of Technology

Atlanta, GA 30332

J. Park

HELION, Inc.

Box 445

Brownsville, CA 95919

Dr. T. R. Kornreich

JBF Scientific Corporation

1925 North Lynn Street

Suite 308

Arlington, VA 22209

Dr. J. B. Knox

Lawrence Livermore Laboratory

University of California

P. 0. Box 808

Livermore, CA 94550 
No. of

Copies

Ms. Abbey Page

Maine Office of Energy Resources

55 Capitol

Augusta, ME 04330

S. M. Howard

Meteorology Research, Inc.

P. 0. Box 637

Altadena, CA 91001

V. F. Garrett

Montana Energy and MHD Res. and

Dev. Inst., Inc.P. 0. Box 3809

Butte, MT 59701

J. Konigsberg

Montana Energy Office

Capital Station

Helena, MT 59601

Phillip French

NASA Scientific and Technical Information Facility

P. 0. Box 8757

Baltimore/Washington International

Airport

MD 21240

R. A. Wolf

NASA/Lewis Research Center

Mail Stop 500-201

Cleveland, $\mathrm{OH} 44135$

M. J. Changery

National Oceanic and Atmospheric Administration

National Climatic Center

Federal Building

Asheville, NC 28801

R. J. Templin

National Research Council of

Canada

National Aeronautical Establishment

M-2 Montreal Road

Ottawa, Ontario KIA or 6
No. of

Copies

Ms. Peggy McDonald

N. E. Solar Energy Center

70 Memorial Drive

Cambridge, MA 02142

P. W. Blakeley

New Zealand Electricity

Rutherford House

Lambton Quay

Wellington, New Zeal and

M. W. Edelstein

North American Weather Consultants 600 Norman Firestone Road

Goleta, CA 93017

R. B. Corotis

Civil Engineering - Tech.

Northwestern University

Evanston, IL 60201

E. W. Hewson

Oregon State University

Corvallis, OR 97331

R. de Violini

Pacific Missile Test Center

CODE 3250-3

Point Mugu, CA 93042

S. C. Crow

Poseidon Research

11777 San Vincente Blvd.

Suite 641

Los Angeles, CA 90049

D. Tompkins

PRC Eng. Analysis Co.

7600 01d House Road

McLean, VA 22102

Dr. F. M. Vukovich

Research Triangel Institute

P. 0. Box 12194

Research Triangle Park, NC 27709 
No. of

Copies

Terry J. Healy

Rockwell International

Rocky Flats Plant

P. 0. Box 464

Golden, C0 80401

2 R. E. Akins/J. W. Reed

Sandia Laboratories

Division 5443

P. 0. Box 5800

Albuquerque, NM 87115

R. M. Traci

Science Applications, Inc.

P. 0. Box 2351

La Jolla, CA 92038

D. M. Hardy

Solar Energy Research Institute

1536 Cole Blvd.

Golden, CO 80401

Dr. C. M. Bhumralkar

Stanford Research

Institute, International

Menlo Park, CA 94025

C. Jump

US Army Corps of Engineers

Seattle District

P. 0. Box C 3755

Seattle, WA 98124

B. H. Bailey

Atomospheric Sciences Research Center SUNY Al bany - ES 324

Albany, NY 12222

R. Crowder

Taylor Woodrow Construction, Limited

Taywood House

345 Ruislip Road

Southal 1

Middlesex UBI 2QX

England
No. of

Copies

Dr. T. Wentink, Jr.

University of Alaska

Fairbanks, AK 99701

Dr. P. Yuen

University of Hawai at Manoa

Holmes Hall 240

2540 Dole Street

Honolulu, HI 96822

C. E. Duchon

University of $0 \mathrm{Kl}$ ahoma

200 Felgar Street

Norman, OK 73069

Dr. N. K. Wagner

Dept. of Civil Engineering

University of Texas

Austin, TX 78712

Dr. M. Garstang

University of Virginia

Charlottesville, VA 22903

Dr. R. W. Marrs

University of Wyoming

Laramie, WY 82071

David Kapus

Washington State Division of

Engineering and Architecture

106 Maple Drive

01 ympia, WA 98504

Ms. Susan Hosch

Washington State Energy Office $400 \mathrm{E}$. Union Avenue, lst Floor

01ympia, WA 98504

R. K. Woodruff

Washington Public Power Supply System

P. 0. Box 968

Richland, WA 99352 
No. of

Copies

S. R. Epur

Wichita State University

P. 0. Box 44

Wichita, KS 67208

\section{ONSITE}

2 DOE Richland Operations Office

P. 0. Box 550

Richland, WA 99352

R. K. Stewart

H. E. Ransom

39 Pacific Northwest Laboratory

Battelle Boulevard

Richland, WA 99352

W. C. Cliff (10)

R. L. Conley

J. R. Connel 1

J. C. Doran

R. L. Drake

C. E. Elderkin (5)

D. L. Elliot

M. M. Orgill

P. M. Partch

W. T. Pennell

E. H. Phinney

J. V. Ramsdel 1

D. S. Renne

C. L. Simpson

L. L. Wendell (5)

Technical Information - Library (5)

Publishing Coordination (2) 
